\title{
Conferința Națională de Psihologie Industrială şi Organizațională
}

\section{Ediția a VII -a}

\section{0 - 13 Mai 2007, Cluj Napoca}

Asociația de Psihologie Industrială şi Organizațională (APIO), în colaborare cu Facultatea de Psihologie şi Ştiințe ale Educației, Catedra de Psihologie, organizează în perioada 10 - 13 mai 2007, la Cluj Napoca, Ediția a VII a Conferintei Naționale de Psihologie Industrială și Organizațională.

Secțiunile conferinței sunt următoarele:

- Managementul Resurselor Umane

- Cultură, Schimbare şi Dezvoltare Organizațională

- Ergonomie Cognitivă

- Psihologie Militară

- Psihologia Reclamei şi Consumatorului

- Emoții în Organizații

Conferința va include pe lângă prezentarea lucrărilor şi o masă rotundă cu tema "Implementarea abordării scientist - practitioner în practica organizațională" şi o secțiune de workshopuri cu următoarele teme:

- METODOLOGIA ELABORĂRII ŞI IMPLEMENTĂRII UNUI CENTRU DE EVALUARE: ELEMENTE PRACTICE

- METODE DE ANALIZĂ COMPUTERIZATĂ A DATELOR

- TENDINȚE ACTUALE DE CERCETARE ÎN ROMÂNIA

- DIAGNOZA EMOȚIILOR ÎN CONTEXT ORGANIZAȚIONAL. ABORDĂRI METODOLOGICE

Vă aşteptăm cu drag!

\section{COMITET ŞTIINṬIFIC INVITAT}

- $\quad$ Prof. Univ. Dr. Pitariu D. Horia, Universitatea Babeş Bolyai, Cluj Napoca

- Prof. Univ. Dr. Nicolae Mitrofan, Universitatea din Bucureşti, Bucureşti

- $\quad$ Prof. Univ. Dr Mihai Aniței, Universitatea din Bucureşti, Bucureşti

- $\quad$ Prof. Univ. Dr. Bogathy Zoltan, Universitatea de Vest, Timişoara

- Conf. Univ. Dr. Sofia Chirică, Universitatea Babeş Bolyai, Cluj Napoca

- Conf. Univ. Dr. Ticu Constantin, Universitatea „Al. I. Cuza”, Iaşi

- Conf. Univ. Dr. lliescu Dragoş, SNSPA, Bucureşti

- $\quad$ Lect. Univ. Dr. Dobrean Anca, Universitatea Babeş Bolyai, Cluj Napoca

\section{COMITETUL DE ORGANIZARE}

- $\quad$ Prof. Univ. Dr. Pitariu D. Horia, Universitatea Babeş Bolyai, Cluj Napoca

- $\quad$ Drd. Budean Andreea, Universitatea Babeş Bolyai, Cluj Napoca

- Drd. Capotescu Roxana, Universitatea Babeş Bolyai, Cluj Napoca

- $\quad$ Drd. Ciuce Cătălina, Universitatea Babeş Bolyai, Cluj Napoca

- Drd. Onacă Daniela, Universitatea Babeş Bolyai, Cluj Napoca

- $\quad$ Drd. Rîlea Veronica, Universitatea Babeş Bolyai, Cluj Napoca

- Masterand Popa Mihaela, Universitatea din Bucuresti, Bucuresti 


\title{
METODE COMPUTERIZATE DE ANALIZĂ A DATELOR
}

Prof. univ. dr. Ioan Radu, Prep. Univ. drd. Robert Balazsi, Asist. Cercet. drd. Gabriel Vonaş.

\section{Rezumat:}

O componentă esențială a cercetării ştințifice în psihologie este analiza şi interpretarea datelor numerice obținute. În acest scop, softul SPSS oferă o varietate de funcții statistice: de la crearea bazelor de date, şi până la metodele standardizate de inferență statistică.

\section{Obiective:}

Workshopul de față, îşi propune asimilarea unor cunoştințe legate de utilizarea softurilor experimentale şi analiza statistică în cercetarea curentă, precum şi formarea deprinderilor necesare analizei statistice a datelor cercetării utilizând softul SPSS.

\section{Tematica propusă:}

1. Prezentarea softului SPSS: avantajele utilizării SPSS-ului în cercetarea experimentală.

2. Definirea variabilelor independente şi dependente în SPSS.

3. Date lipsă şi strategii de suplinire a datelor lipsă.

4. Modalități de reprezentare grafică în SPSS.

5. Statistica inferențială asistată de SPSS.

6. Analiza de varianță asistată de SPSS.

7. Calculul corelației (corelații parametrice şi non-parametrice).

8. Analiza de regresie simplă.

\section{Beneficiari:}

Acest workshop se adresează studenților sau absolvenților de psihologie, psihologilor practicieni sau specialiştilor implicați în activități de cercetare sau evaluare.

\section{DIAGNOZA EMOȚIILOR ÎN CONTEXT ORGANIZAȚIONAL. ABORDĂRI METODOLOGICE.}

\author{
Prof. Univ. Dr. Horia D. Pitariu, Drd. Roxana Capotescu, Drd. Daniela Onacă, Drd. Vlad Tureanu
}

\section{Obiective:}

Familiarizarea psihologilor din domeniul industrial-organizational cu problematica investigarii emoțiilor in organizații si a implicațiilor acestora în diverse procese organizaținale;

Eficientizarea managementului resurselor umane prin includerea componentei de management al emoțiilor in organizații;

Standardizarea demersurilor în domeniul emoțiilor în organizații prin stabilirea unui cadru metodologic comun, fundamentat pe baze ştiințifice;

Includerea evaluării emoțiilor în organizații ca parte integrantă a demersurilor de diagnoză şi psihodiagnoza organizațională precum şi în procesele de proiectare şi implementare tehnologică.

\section{Tematica:}

Conținuturile acestui workshop vor fi axate în jurul a trei problematici majore:

A. Metode de validare a instrumentelor de evaluare a emoțiilor în organizații - în cadrul acestei tematici va fi prezentat demersul metodologic de validare a unor probe psihologice pentru evaluarea emoțiilor în organizații. Se vor oferi exemple clare pornind de la cercetări de validare aflate in desfăşurare. Vor fi înaintate participanților studii de caz orientate pe evaluarea emoțiilor în organizații ce activează în domenii diferite. 
B. Aplicații practice privind diagnoza emoțiilor în organizații - în cadrul acestei teme activitatea va fi orientată în jurul unui instrument deja validat pe populație românească, ASSET. Vor fi prezentate tehnica aplicării instrumentului, posibilitățile de analiză computerizată a profilelor obținute, precum şi posibilitățile multiple de aplicare în practică a rezultatelor.

C. Investigarea emoțiilor în procesul de design al produselor informatice. Evaluarea utilizabilității - în cadrul acestei tematici vom oferi un cadru de analiză a emoțiilor implicate in domeniul proiectarii sistemelor informatice. Vom supune analizei unui studiu de caz asupra procesului de implementare a unui sistem computerizat interactiv intr-o bancă.

\title{
Beneficiari:
}

Psihologi ce activează în domeniul industrial-organizațional, psihologi specializați în psihodiagnostic organizațional, cercetători interesați în domeniul emoțiilor şi managementului emoțiilor în organizații şi specialişti în managementul resurselor umane.

\section{METODOLOGIA ELABORĂRII ŞI IMPLEMENTĂRII UNUI CENTRU DE EVALUARE: ELEMENTE PRACTICE}

\author{
Psih. Ma. HANGA Camelia, Drd. CIUCE Cătălina, Drd. ONACĂ Daniela
}

\section{Rezumat}

Centrele de evaluare, ca metodologie aplicată în procesele de management al resurselor umane, a fost utilizată pe larg în ultimii patruzeci-cincizeci de ani inițial în Statele Unite şi în general de către marile corporații, cu extindere ulterioară la nivel internațional (Bray, Campbell, \& Grant, 1974; Howard, 1974; Howard \& Bray, 1988; Gatewood \& Feild, 1994) în scopul selecției de personal, promovării, trainingului şi furnizării de feedback asupra necesităților de dezvoltare a angajaților care ocupă posturi la nivel executiv.

\section{Obiectivul}

Obiectivul acestui workshop este de a furniza participanților cunoştințele necesare proiectării şi implementării unui centru de evaluare, în acord cu principiile de elaborare adoptate la nivel international.

\section{Tematica:}

Tematica propusă vizează în primul rând realizarea unei analize comparative a tipurilor de centre de evaluare din punct de vedere a metodologiei de elaborare, tipurilor de activități realizate şi modalitatea de utilizare a rezultatelor obținute.

În partea a doua a workshopului participanții vor avea ocazia de a exersa elaborarea unui centru de evaluare în scopul selecției de personal şi de a a fi implicați activ în simularea implementării lui pe marginea unor studii de caz.

\section{Beneficiari:}

Acest workshop se adresează psihologilor sau specialiştilor care operează în domeniul resurselor umane. 